\title{
Impact of Long-term Employment of a Self-Management Program in Asthmatics
}

\author{
Gilles Devouassoux ${ }^{1^{*}}$, Nathalie Freymond ${ }^{2}$, Laurent Laforest ${ }^{3}$, Thierry Vitry ${ }^{2}$, Alexis Cazaux ${ }^{2}$ and Yves Pacheco $^{2}$ \\ ${ }^{1}$ Service de Pneumologie, Hôpital de la Croix-Rousse et INSERM U851, France \\ ${ }^{2}$ Service de Pneumologie, Centre Hospitalier Lyon Sud, France \\ ${ }^{3}$ Unité de Pharmaco-Epidémiologie, Hôpital Pierre Wertheimer, Hospices Civils de Lyon et Université Claude Bernard, Lyon, France
}

\begin{abstract}
Background: Self-management of asthmatics is thought to facilitate early detection and treatment of asthma exacerbations, and to reduce asthma-related morbidity and mortality.
\end{abstract}

Aim: To evaluate the efficacy of a self-management program on the long-term follow-up of asthma and determine the factors influencing the success of such program in asthmatic patients.

Methods: Objective parameters (criteria of asthma control, $\mathrm{FEV}_{1}$ and $\mathrm{FEV}_{1} / \mathrm{FVC}$ ) were assessed at inclusion and at the end of the retrospective study, $8.9 \pm 8$ years later, using a 1-year recall patient-based questionnaire and lung function measurements.

Results: Among the 112 patients who answered the questionnaire ( $63 \%$ of response), 69 patients followed the self-management program, either partially with the help of a phone call to their physician $(22 \%)$ or exclusively $(78 \%)$, the latter displaying higher education levels $(p<0.05)$. In the "self-management" group, GINA status was stabilized or improved $(80 \%)$, FEV , was significantly improved, a less frequent use of emergency services was reported, corticosteroid dependence was reduced $(22 \%$ vs. $7 \%, p=0.03)$ and smoking dropped $(p=0.05)$. Additionally, higher global quality of life scores were obtained in the self-management group $(21 \%$ vs. $7.9 \%, p=0.05)$.

Conclusion: A self-management program significantly improved control of asthma and quality of life of asthmatics. Because control of asthma is lacking for the vast majority of asthmatics, these results argue for an usual employment of such program in the long term follow-up of asthmatics.

Keywords: Therapeutic education; Self-management program; Written action plan; Asthma; quality of life; Asthma control

\section{Introduction}

Asthma constitutes a major public health issue, inducing increased morbidity and mortality, particularly among young subjects, with an important economic burden, mainly related to exacerbations [1]. Exacerbations of asthma may arise even in partially and well-controlled asthma [2,3]. Furthermore, patients' assessment of asthma control remains tricky and challenging, leading to delay the management of exacerbations and responsible for tremendous hospitalisations and emergency consultations [4].

These findings have led to particular attention being drawn to the benefits of written action plans, advising patients on how to recognize the need for a change in therapy in case of exacerbation and how to manage their treatment [5-7]. However, providing written plans alone is not sufficient. In order to be able to manage their illness themselves, patients need to acquire sufficient knowledge about their disease through self-management programs. The aims of those programs are also to promote self management of asthmatics, to be able by themselves to both modulate treatment and to solicit medical assistance when required.

Different studies have proved the usefulness of self-management programs and shown that it was more beneficial than an isolated conventional therapeutic approach [8-11]. Despite their recognized benefits, the application of self-management program remains underused. Limitations are due to physicians, unconfident with their effectiveness and to patients, who have difficulties to follow a longterm action plan, particularly when asthma appears stabilized [12-15]. Additionally, it has been shown that asthmatics preferred to regulate their treatment according to their symptoms only [16].
The main objectives of our retrospective study were to evaluate the impact of a self-management program on asthma in a cohort of patients followed-up for more than 1 year and to assess the factors, which may influence the success of such program.

\section{Methods}

\section{Patients and study design}

This retrospective study was conducted in the Department of Respiratory Medicine, Centre Hospitalier Lyon Sud, Lyon, France, from 1989 to 2005. Based on medical files analysis, patients included in this study had asthma, diagnosed by a physician, with at least a $12 \%$ increase in FEV-1 after a short-acting bronchodilator inhalation, and with a regular medical followed-up for at least 1 year. Patients under 15 years-old were excluded, as well as patients with either a smokingrelated COPD or other chronic cardio-respiratory diseases.

A self-management educational program was systematically proposed to any asthmatic patients followed in the Department of Respiratory Medicine, as described below (cf. intervention: selfmanagement program). After at least 1 year, following the initial

*Corresponding author: Gilles Devouassoux, Service de Pneumologie, Hôpital de la Croix Rousse 103, Grande-Rue de la Croix-Rousse 69317 Lyon cedex 04, France, Tel: 33426732947; Fax: 33472072413; E-mail: gilles.devouassoux@chu-lyon.fr

Received March 16, 2017; Accepted October 16, 2017; Published October 23, 2017

Citation: Devouassoux G, Freymond N, Laforest L, Vitry T, Cazaux A, et al. (2017) Impact of Long-term Employment of a Self-Management Program in Asthmatics. J Pulm Respir Med 7: 426. doi: 10.4172/2161-105X.1000426

Copyright: (c) 2017 Devouassoux G, et al. This is an open-access article distributed under the terms of the Creative Commons Attribution License, which permits unrestricted use, distribution, and reproduction in any medium, provided the original author and source are credited. 
session of the program, a questionnaire was send to all patients of the program. Answers to questionnaire allowed to identify the adherence to the program, to assess asthma control and quality of live. Based on declarations of adherence or not to the self management program, 2 groups of asthmatics were individualized.

\section{Intervention: self-management program}

Briefly, the self-management program consisted in 2 sequential educational sessions, delivered in identical 1 hour visits, separated from 1 to 3 months. During education session, patients were coached by physician, trained nurse and physiotherapist. Learning sessions were provided, concerning the employment, usefulness and rational of anti-asthmatic treatments, peak flow training, recognition of the loss of asthma control, using both clinical symptoms and by measuring peak expiratory flow. In addition, they received an educational "asthmapack", designed by the medical-care working group, for additional self-sessions at home. Finally, patients received a written action plan, including specific mentions of the therapeutic steps to be followed, according to fluctuations of peak expiratory flow (Table 1).

\section{Outcome}

The main criterion of the efficacy of the self-management program on asthma control was assessed by measuring objective clinical and paraclinical parameters according to GINA criteria of asthma control [17] (daytime and nocturnal/awakening symptoms, limitation of activities, need for rescue treatment, lung function, exacerbations), at inclusion (D0) and at the end of the study. Quality of life (QoL), use of peak flow monitoring, use of the management program and global satisfaction of the patients were also evaluated.

\section{Asthma control, quality of life questionnaire and Spirometry}

With the exception of lung function parameters (maximum expiratory volume per second $\left(\mathrm{FEV}_{1}\right)$ and Tiffeneau coefficient), which were measured by the investigator, all data were collected using a patient's questionnaire based on a 1-year recall. This questionnaire was developed from both asthma control and quality of life questionnaires used to date in the evaluation of asthmatic disease $[18,19]$. It was made up of 4 parts: the first part established the initial clinical and socio-

\begin{tabular}{|c|c|}
\hline 1) & Fall in peak flow rate: $<20 \%$ of the theoretical rate \\
\hline & No immediate therapeutic change \\
\hline & Repeat peak flow monitoring several times/day \\
\hline & If persists $>48$ hours, follow $\S 2 a$ \\
\hline \multirow[t]{9}{*}{ 2) } & Fall in peak flow rate: $20-30 \%$ \\
\hline & a) Increase the treatment: \\
\hline & Short acting $\beta 2$ agonist (SABA): 2 puffs $\times 3 /$ day \\
\hline & Increase inhaled corticosteroids: 2 puffs $\times 5 /$ day \\
\hline & b) If this is insufficient after $48 \mathrm{~h}$ : \\
\hline & $\begin{array}{l}\text { Aerosol } \times 3 / \text { day (betamethasone } 4 \mathrm{mg} \text {, salbutamol } 1 \mathrm{mg} \text { ) } \\
\text { during } 3-5 \text { days, then } \mathrm{x}_{2} / \text { day the following days }\end{array}$ \\
\hline & c) According to the $48 \mathrm{~h}$ results: \\
\hline & If normal peak flow rate: continue step $2 b) \times 10$ days \\
\hline & $\begin{array}{l}\text { - } \begin{array}{l}\text { Otherwise, prednisolone } 20 \mathrm{mg} / \mathrm{d} \times 8 \text { days followed by } \\
\text { prednisolone } 10 \mathrm{mg} / \mathrm{d} \times 8 \text { days }\end{array}\end{array}$ \\
\hline \multirow[t]{2}{*}{ 3) } & Fall in peak flow rate $>30 \%$ or step $2 \mathrm{c}$ ) insufficient \\
\hline & $\begin{array}{l}\text { Aerosol step } 2 \mathrm{~b})+ \text { Prednisolone } 40 \mathrm{mg} / \mathrm{d} \times 8 \text { days, then } \\
\text { gradually reduce by } 10 \mathrm{mg} \text { every } 5 \text { days }\end{array}$ \\
\hline \multirow[t]{4}{*}{ 4) } & Failure of step 3 ) or fall in peak flow rate $>50 \%$ \\
\hline & Contact a doctor or the emergency services \\
\hline & Start or continue aerosol step $2 \mathrm{~b}$ ) \\
\hline & Adopt respiratory relaxation posture \\
\hline
\end{tabular}

Table 1: Individual action plan: chronological therapeutic steps. demographic characteristics of the patient. The second part focused on the levels of asthma control according to GINA criteria, use of oral corticoids and use of peak flow monitoring. The third section dealt with limitations of activities and with health-related QoL, and the fourth part with the way the patients used the self-management program, their overall satisfaction with regard to the action plan and their general opinion on the use of such educative programs for asthmatics.

The part of the questionnaire dealing with QoL was largely inspired by the JUNIPER questionnaire 18,19 validated for reliability and its ability to measure QoL in an adult asthmatic population. The domains investigated were physical state, psychological and emotional state, and environmental conditions. A global score of QoL from 0 to 8 was calculated on the basis of the answers to the questionnaire.

\section{Statistics}

Statistical analysis was performed with SAS 8 software. Quantitative parameters were expressed by numbers of patients, mean \pm standard deviation, and qualitative parameters by number and percentage of patients. Univariate analysis of QoL scores comparing self-management and no self-management groups was performed by Kruskal-Wallis test. Statistical tests were performed using a statistical significance threshold of 0.05. Changes in quantitative parameters from D0 until the end of the study were assessed with matched t-tests.

\section{Results}

\section{Patients flow and characteristics at baseline}

Among the 187 asthmatics who were recruited in this study based on their medical file analysis, 117 subjects (62.5\%) agreed to fill in the questionnaire, ( $52 \%$ women, $48 \%$ men), average age ( $53 \pm 18$ years), and finally 112 filled out the questionnaire and were included in the analysis. The mean duration of self-management was $8.9 \pm 8$ years.

The patients who did not fill out the questionnaire $(n=75)$ were predominantly males (53\%), a large proportion had only primary education (46.5\%) and their asthma was mainly moderate to severe (GINA stage III and IV, 70\%). They were on average younger than the patients who answered the questionnaire ( $45.3 v s .53$ years) and were more often currently smoking ( $23.5 \%$ vs. $7 \%$ among the 117 patients who agreed to fill in the questionnaire, $\mathrm{p}=0.05)$.

Among the group of 112 patients included in the study, 69 accepted the principle of self-management and 43 refused. Among the first group of 69 subjects, $78 \%$ carried out real self-management, $22 \%$ carried out partial self-management with the help of a phone call to their general physician.

The demographic, socio-economic, clinical and therapeutic characteristics of the 117 subjects are listed in Table 2. Asthma had been present for more than 10 years in $73 \%$ of cases, more than 5 years in $22.6 \%$ and less than 5 years in $4.3 \%$. Among the other characteristics of the study population, $65 \%$ had atopic dermatitis, $59 \%$ had an asthma-associated rhinitis, $66 \%$ had never smoked and $27 \%$ were former smokers. With regards to treatment, $71 \%$ used an association of corticosteroid/long-acting beta-2 agonist inhalers, $25 \%$ took leukotriene receptor antagonists, $30 \%$ antihistamines $15 \%$ a systemic steroid therapy and $71 \%$ were fully covered by the French National social security fund (Table 2).

\section{Study duration}

The study lasted a minimum of twelve months, but a majority 


\begin{tabular}{|c|c|}
\hline Characteristics & \\
\hline Male/Female & $52 \% / 48 \%$ \\
\hline Age $($ mean \pm SD) & $52.9 \pm 17.9$ years \\
\hline $\begin{array}{l}\text { Educational level } \\
\text {-Primary } \\
\text {-Secondary } \\
\text {-Further education } \\
\end{array}$ & $\begin{array}{l}46.5 \% \\
36.8 \% \\
16.7 \% \\
\end{array}$ \\
\hline $\begin{array}{l}\text { Professional activity } \\
\text {-active } \\
\text {-retired } \\
\text {-unemployed }\end{array}$ & $\begin{array}{l}43 \% \\
47 \% \\
10 \% \\
\end{array}$ \\
\hline Familial atopy & $51 \%$ \\
\hline Personal atopy & $65.5 \%$ \\
\hline Domestic animals & $38 \%$ \\
\hline $\begin{array}{l}\text { Smoking } \\
\text {-Non-smoker } \\
\text {-Former smoker } \\
\text {-Current smoker }\end{array}$ & \begin{tabular}{|l|}
$66 \%$ \\
$27 \%$ \\
$7 \%$ \\
\end{tabular} \\
\hline $\begin{array}{l}\text { Duration of asthma }(\text { mean } \pm \mathrm{SD}) \\
<5 \text { years } \\
5-10 \text { years } \\
>10 \text { years }\end{array}$ & $\begin{array}{l}20.2 \pm 11.6 \text { years } \\
5 \% \\
22 \% \\
73 \% \\
\end{array}$ \\
\hline $\begin{array}{l}\text { GINA stage } \\
\text { I } \\
\text { II } \\
\text { III } \\
\text { IV } \\
\end{array}$ & \begin{tabular}{|l|l} 
& $1 \%$ \\
$28.4 \%$ \\
$37.25 \%$ \\
$33.3 \%$ \\
\end{tabular} \\
\hline $\begin{array}{l}\text { Fully covered }(100 \%) \text { by the National social security } \\
\text { fund }\end{array}$ & $71 \%$ \\
\hline $\begin{array}{l}\text { Current therapy } \\
\text {-Inhaled corticosteroids } \\
\text {-Anti LT receptors } \\
\text {-Systemic corticosteroids }\end{array}$ & $\begin{array}{l}72 \% \\
24.3 \% \\
15 \%\end{array}$ \\
\hline LT: Leukotrienes & \\
\hline
\end{tabular}

Table 2: Patient characteristics $(n=117)$.

(75.6\%) of the patients had been given the action plan for more than 2 years.

\section{Global asthma evolution for the study population}

For the 112 patients who completed the questionnaire, clinical and paraclinical data recorded both at the time of the original action plan (start of study) and at the date of completing the questionnaire (end of study) were compared. GINA severity score was significantly improved between the start and end of study (Figure 1). GINA severity scores were improved in $39.13 \%$ of patients and remained stable for $40.5 \%$.

$\mathrm{FEV}_{1}$ was significantly improved at the end of study compared to the beginning $(79.3 \pm 22.9$ vs. $74.3 \pm 22.9)$. Among the 85 patients for whom FEV values were available at the beginning and end of the study, a significant improvement was observed $(p=0.037)$. At the end of the study compared with D0, the percentage of patients with $\mathrm{FEV}_{1}<60 \%$ was lower while the percentage of patients with a $\mathrm{FEV}_{1}>80 \%$ was higher (Table 3). This improvement was essentially observed in patients during the first 6 years of follow-up $(n=38,+8.16, p=0.009)$, whereas for patients with more than 6 years follow-up $(n=47,+0.09, \mathrm{p}=\mathrm{NS})$, an overall stabilisation of the $\mathrm{FEV}_{1}$ was observed.

In addition, a significant reduction in the number of smokers from $23 \%$ at the time of the action plan to $7 \%$ at the time of the questionnaire, a reduction in emergency consultations (decreased in $57 \%$ of patients and stabilised in $37 \%, \mathrm{p}<0.05$ ), a decrease in the use of oral corticosteroids (decrease in $31 \%$ of patients and stabilisation in $46 \%)$, were observed.

\section{Asthma improvement according to self-management}

Among the 112 patients, two subgroups were compared according

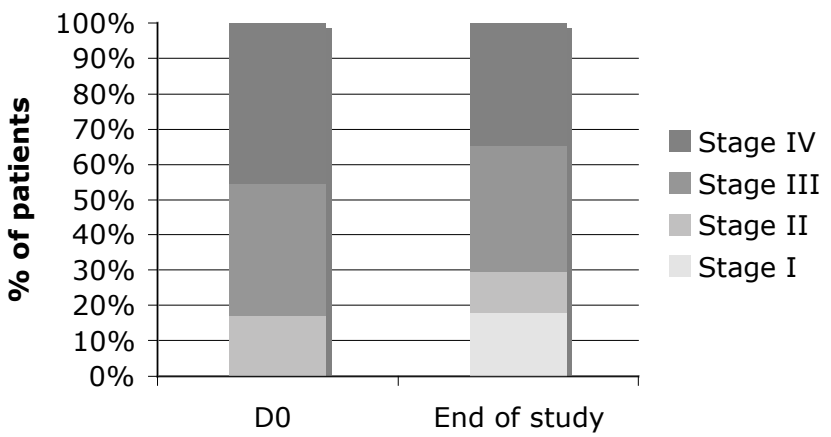

Figure 1: Distribution of patients according to GINA stage at D0 (self-management program delivery, $n=88$ ) and end of the study (questionnaire filling, $n=78$ ).

\begin{tabular}{|l|c|c|}
\hline FEV1 (\% predicted) & $\begin{array}{c}\text { D0 } \\
\mathbf{n}(\%)\end{array}$ & $\begin{array}{c}\text { End of study } \\
\mathbf{n}(\%)\end{array}$ \\
\hline Assessable population $\mathbf{( n / 1 1 7 )}$ & 100 & 85 \\
\hline $\mathbf{< 6 0 \%}$ & $27(27.0 \%)$ & $20(23.5 \%)$ \\
\hline $\mathbf{6 0 - 8 0} \%$ & $38(38.0 \%)$ & $25(29.4 \%)$ \\
\hline $\mathbf{> 8 0} \%$ & $35(35.0 \%)$ & $40(47.1 \%)$ \\
\hline Missing data $(\mathbf{n})$ & 17 & 32 \\
\hline
\end{tabular}

Table 3: Distribution of patients according to FEV1 at D0 and at the end of the study.

to their management status. Results are presented in Table 4. The comparison showed a nearly significant decrease in long-term steroid employment ( $\mathrm{p}=0.03)$, short-term use of oral corticosteroids $(\mathrm{p}=0.05)$, emergency consultations or hospitalisations $(\mathrm{p}=0.05)$ and significant increase in QoL $(\mathrm{p}=0.04)$ in the self-management group $v$ s. the no selfmanagement group.

Among the group of 69 patients who claimed self-management, the initial therapeutic response in the event of an acute asthmatic attack was: To double the number of inhaled treatment intakes (30\%); to use aerosols (34\%), to use oral corticosteroids (7\%) and to use both aerosol treatment and oral corticosteroids (30\%). Seventy percent of patients reported changing their treatment from the start of the attack.

\section{Quality of life}

In the framework of univariant analysis of self-management of asthma, a significant difference was found between subjects who managed their disease themselves and those who did not, regarding the improvement of global QoL score $(+2.58 v s .+2.15, \mathrm{p}=0,04)$ and daily limitations $(\mathrm{p}=0.04)$ (Figure 2). Indeed, less important daily limitations were perceived in social relations, leisure and professional activities, less necessary adaptations of the environment due to asthma and less constraints linked to anti-asthmatic treatments were declared by $55.4 \%$ of the self-management group vs. $33.4 \%$ of the non self-management group. The percent of patients who did not perceive their disease as restricting, distressful or depressing was higher in the self-management group ( $37 \%$ vs. $27.5 \%$, p < 0.05 ). Higher global QoL scores were obtained by $21 \%$ of patients in the self-management group $v s .7 .9 \%$ in the non self-management group $(\mathrm{p}<0.05)$.

Among individuals from the self-management group, patients who did not call their general practitioner had a significantly better quality of life than those who called their doctor. When educational levels of the patients were considered, a significant association with improved QoL was found in patients with further or secondary level education ( $\mathrm{p}=0.0018$ ) but not in those with only primary education. Quality of life 
Citation: Devouassoux G, Freymond N, Laforest L, Vitry T, Cazaux A, et al. (2017) Impact of Long-term Employment of a Self-Management Program in Asthmatics. J Pulm Respir Med 7: 426. doi: 10.4172/2161-105X.1000426

Page 4 of 7

is therefore significantly improved only in patients who have a certain level of education.

Although $64.5 \%$ of subjects considered their disease was restricting, $87 \%$ felt, however, that they could still continue a normal life thanks to the self-management program.

\begin{tabular}{|c|c|c|c|}
\hline & $\begin{array}{c}\text { Self- } \\
\text { management }\end{array}$ & $\begin{array}{c}\text { No self- } \\
\text { management }\end{array}$ & $p$ value \\
\hline$N(\%)$ & $69(61.6 \%)$ & $43(38.4 \%)$ & \\
\hline Age (years) & $50.4 \pm 17.7$ & $56.9 \pm 17.7$ & \\
\hline Male (n)/Female (n) & $37 / 32$ & $26 / 17$ & NS \\
\hline $\begin{array}{l}\text { Educational level } \\
\text { Primary (\%) } \\
\text { Secondary/higher (\%) }\end{array}$ & $\begin{array}{l}39.4 \\
60.6\end{array}$ & $\begin{array}{l}61.9 \\
38.1\end{array}$ & 0.02 \\
\hline $\begin{array}{l}\text { Fully covered by the National } \\
\text { social security fund (\%) }\end{array}$ & 71.2 & 73.8 & NS \\
\hline 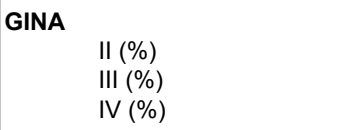 & $\begin{array}{c}30 \\
38.3 \\
31.7\end{array}$ & $\begin{array}{l}30.6 \\
30.6 \\
38.9\end{array}$ & NS \\
\hline Steroid dependence (\%) & 22 & 7 & 0.03 \\
\hline \begin{tabular}{|} 
Duration of asthma \\
$<5$ years $(\%)$ \\
$5-10$ years $(\%)$ \\
$>10$ years $(\%)$
\end{tabular} & $\begin{array}{c}6 \\
19.4 \\
74.6\end{array}$ & $\begin{array}{c}2.3 \\
25.6 \\
72.1\end{array}$ & NS \\
\hline $\begin{array}{l}\text { Length of use of action plan } \\
<2 \text { years }(\%) \\
>2 \text { years }(\%)\end{array}$ & $\begin{array}{l}26.9 \\
73.1\end{array}$ & $\begin{array}{l}20.9 \\
79.1\end{array}$ & NS \\
\hline $\begin{array}{l}\text { Short term use of } \\
\text { corticosteroids } \\
\text { Decrease (\%) } \\
\text { Increase or no change } \\
(\%)\end{array}$ & $\begin{array}{l}41.5 \\
58.5\end{array}$ & $\begin{array}{l}27.6 \\
72.4\end{array}$ & 0.05 \\
\hline $\begin{array}{l}\text { Emergency consultation or } \\
\text { hospitalisation (decrease \%) }\end{array}$ & 56 & 35 & 0.05 \\
\hline Improvement QOL (score) & 2.58 & 2.15 & 0.04 \\
\hline
\end{tabular}

Table 4: Comparison of self-management and no self-management groups.

\section{Evaluation of the action plan}

Considerations concerning duration of use of the action plan, adaptation of therapy, understanding of the information provided and feeling that the information is sufficient to start the emergency treatment are listed in Table 5.

Among individuals from the self-management group, the proportion of patients who had to receive emergency medical treatment was significantly lower among patients who did not call their physician. The GINA status and FEV ${ }_{1}$ were comparable in those two self-managing subgroups. The action plan was significantly better understood by patients who did not call their physician in case of exacerbation. The patients who did not call their physician were significantly more likely to say that the information they had received was good enough for them to be able to adapt their treatment on their own in the event of an acute attack. In the group of patients who did not call their physician, educational levels were significantly higher (Table 4).

\begin{tabular}{|l|c|}
\hline $\begin{array}{l}\text { Duration of use of the action plan } \\
\quad<2 \text { years }\end{array}$ & $24 \%$ \\
$>2$ years & $76 \%$ \\
\hline & \\
\hline Adaptation of therapy & $78 \%$ \\
$\quad$ By the patient on his/her own (immediate 70\%, delayed 30\%) & \\
With medical assistance & $22 \%$ \\
As indicated in the action plan & $86 \%$ \\
According to symptoms & $96 \%$ \\
According to the \% fall in peak flow rate: & $27.5 \pm 10 \%$ \\
$\quad<20 \%$ & $22 \%$ \\
$20-30 \%$ & $45 \%$ \\
$>30 \%$ & $33 \%$ \\
& \\
\hline Understanding & \\
Very easy & $59 \%$ \\
Easy & $37 \%$ \\
Not easy or difficult & $4 \%$ \\
\hline & \\
\hline Sufficient information to start the treatment & \\
Sufficient & $3 \% \%$ \\
Need for further education/training & \\
\hline Not sufficient, it's a 'medical job' & \\
\hline
\end{tabular}

Table 5: Evaluation of the action plan.

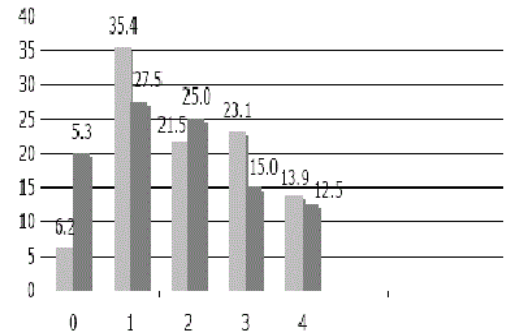

QoL score 1: Patients feeling about asti 2(a)

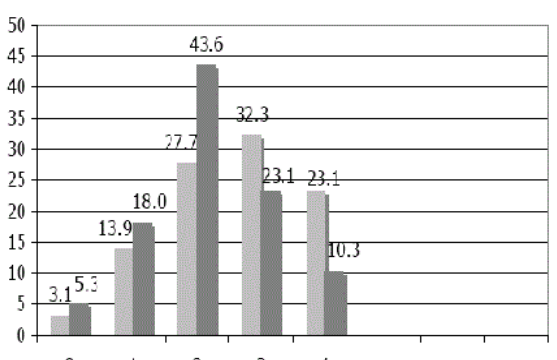

QoL score $2: \stackrel{2}{2} \stackrel{3}{\text { Patients daily limitation }}$ 2(b)

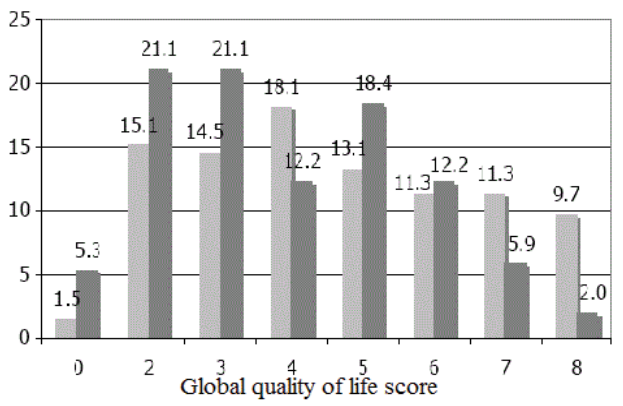

2(c)

Self management group

Non-self management group

Figure 2: Evolution of the quality of life scores. a) Score 1: Patients feelings about their asthma $(n=105$, mean $\pm s d=1.97 \pm 1.25$, median=2.0); b) Score 2: daily limitations $(n=104$, mean $\pm s d=2.48 \pm 1.09$, median=2.0); $)$ Total score $(n=100$, mean $\pm s d=4.41 \pm 2.01$, median=4.0). 


\section{Discussion}

In agreement with the literature, our study confirms over a prolonged period the benefits of patient education and training and of the use of a self-management program as part of the therapeutic choice [20-28].

This retrospective study of a group of 117 patients concerns a population with a particularly long follow-up of more than 2 years for $76 \%$ of the population. This follow-up was longer than those previously described in the literature. Our work shows that the educational impact is maintained over a period of six years with an improvement in different areas, which we detail below, but for patients followed more than six years, we observed a plateau, probably due to the ineluctable worsening of asthma in the most severely affected patients.

As we described in a previous study [29] and as shown elsewhere [15], educational levels significantly influenced patient behaviour and judgements on quality of life in this self-management treatment program. The educational level was significantly higher in patients who completely self-managed their disease without calling their general practitioner.

Information about self-management of their disease by asthmatics is essential for improving morbidity and mortality due to the disease [4]. The Gibson's meta-analysis of 24 asthma self-management programs including an educational section and a periodic medical check-up demonstrated in particular a significant reduction in the proportion of subjects needing hospitalisation, in the number of emergency consultations and non-programmed medical consultations, of days off work for asthma and of nocturnal asthma attacks [30]. Several studies have obtained similar results as well as a reduction in long-term morbidity in adults and children, daytime symptoms, use of drugs for asthma and frequency of psychiatric comorbidities [31,32]. They have also shown an improvement in medication adherence, quality of life, quality of sleep, cognitive ability and self-esteem, and a reduction in the feeling of handicap related to asthma [33]. This point may be an important issue when considering cost/benefit issues.

Accordingly, our study showed a significant reduction in the number of emergency consultations and hospitalisations compared to previous years, as $57 \%$ of patients reported using the emergency services less frequently and $37 \%$ reported no change. Furthermore, results of our study support Gibson's meta-analysis findings [30]. First, the GINA status was improved between the setting up of the action plan and the date of the questionnaire. The $\mathrm{FEV}_{1}$ was also significantly improved but this was only true for patients with a follow-up of less than six years. Nevertheless, patients followed up for more than six years, $\mathrm{FEV}_{1}$ did not changed, which could be explained by the progressive loss of FEV with time in asthmatic patients. Furthermore, smoking had significantly dropped from $23 \%$ to $7 \%$ current smokers between D0 and the end of the study. Given the known noxious effects of tobacco on the breathing functions of asthmatics, this significant reduction is important. Finally, the use of oral corticosteroids fell or remained constant in $77 \%$ of patients who self-managed their disease, suggesting a sparing effect of the self-management program.

Self-management programs have an impact on the quality of life of asthmatics. In our study, $87 \%$ considered that they could lead a normal life thanks to the self-management program. Patients' self-esteem, related to the patient's perceived self-competence, influences stress levels and symptom severity in subjects with chronic illnesses, such as asthma. Self-competence is associated with better asthma control and quality of life [33-35]. Aiming at patient's empowerment is thus a key element of self-management.

Studies undertaken to compare self-management programs based on peak flow monitoring or on symptoms have provided contradictory results: Some failed to show any superiority for either action plan $[30,36]$ whereas others have shown significantly higher self-efficacy scores $(p<0.001)$ and asthma control indicators $(p=0.025)$ [32] and better compliance with the self-management program based on peak flow monitoring [37]. In our study, peak flow monitoring was mainly carried out during periods of fluctuation and instability of asthma, in accordance with authors who recommend monitoring peak flow only during exacerbations and as the acute attack declines [38]. Patients rarely continue regular long-term monitoring and often adapt their selfmanagement to the symptoms. We observed no significant differences between patients who self-managed according to their symptoms and those who self-managed according to peak flow monitoring. Despite the advice and the action plans given to the patients, we found that 43 of the 112 patients did not accept the self-management program and of the remaining 69 who did agree to self-management, $22 \%$ still contacted their physician before making any change in their therapy. The patients who did not call their physician had a significantly better QoL than those who called their physician. The proportion of patients needing emergency services (ambulance, hospitalisation, emergency visit to the general practitioner) was significantly lower among patients who did not call their physician. The willingness of the patient to participate actively in the management of his/her disease was the most important factor and itself depended on numerous other factors, in particular on the patient's own perception of the pathology. Even if a good understanding of the disease by the patient is essential, it is not the determining factor. It is necessary not only that the patient assimilates knowledge but also that he is convinced of its usefulness. At this point his perception of the disease changes, as does his behaviour. General practitioners (GP) are often at the forefront in the management of asthmatics [39-41].

Self-management methods and action plans are more generally used by Anglo-Saxon GPs who have benefited from more widespread use of self-management programs in the USA and in UK $[40,41]$. These studies on self-management and general medicine indicate that it is necessary to more widely spread recommendations for self-management use to GPs because it is easily manageable in daily practice.

Self-management is required to improve the poor understanding of obstructive airway disorders, particularly among at-risk patients, i.e. those with moderate to severe persistent forms of the disease and elderly patients. For Lahdensuo [4], 60\% of asthmatics have difficulty in objectively estimating their respiratory capacity, which is most often insidiously impaired. Other factors calling for self-management include adaptation of patients to their respiratory handicap, which frequently leads to a failure to appreciate rapid worsening of asthma, and poorer understanding of the stable state. Most of adolescents with poor asthma control in particular tend to accept asthma symptoms and have learned to live with them [42]. It has also been observed that the patients often wrongly interpret the improvement phase following an exacerbation while their FEV is still out of the normal range (Pacheco, personal communication). Another factor pleading for the necessity of self-management is the frequently inappropriate therapeutic reactions of patients during an exacerbation. Without complete information, some subjects consider complementary and alternative medicine as safer than short-acting beta agonists, which can lead to inadequate reaction in case of exacerbations [43]. 
This incapacity of patients to judge the severity of their asthma has led to delays in the therapeutic management of acute attacks, which threaten the vital prognosis in the short term [44]. It results in a large number of hospitalisations and emergency consultations, many of which could be avoided by the implementation of self-management techniques. The current priority with self-management is to reduce the delay in treating exacerbations, whether they are acute or more progressive. The aim for patients is to adjust themselves their therapy in case of emergency and judge for themselves when medical assistance is really necessary. In addition, the generally poor compliance of asthmatic patients should also be improved. This implies to identify barriers to self-management, including psychosocial factors, shown to account for $32 \%$ of the variance in total barrier perceptions in adolescents [45]. Internet-based self-management offers a new tool for asthma monitoring and information, which could be used for patients based in remote and underserved areas, both in developed and developing countries [46].

\section{Conclusion}

As a conclusion, self-management forms part of the general training for asthma control and nowadays stands for one of the key elements. However, in addition to self-management methods, patients still need to receive background knowledge about the physiopathology of asthma, the principles of use of the various therapies and the ways of preventing crises and controlling their own environment.

\section{Acknowledgments}

We wish to thank Françoise Nourrit-Poirette, from Santé Active Edition, for her medical writing assistance and her involvement in the drafting of this article, Marielle Romet, from Santé Active Edition, for copy editing and proof-reading.

\section{Declaration of Interest}

NF, TV, AC, LL do not have a financial relationship with a commercial entity in the subject of this manuscript. YP has received lecture fees from MSD and GlaxoSmithKline. GD has received consultancy fees and grant supports from Novartis Pharma. He has received lectures fees from Novartis pharma, GlaxoSmithKline, Chiesi. His institution has received fees from Novartis Pharma, Boehringer Ingelheim, ABscience, GlaxoSmithKline as a site for clinical research trials.

\section{References}

1. Afrite A, Allonier C, Com-Ruelle L, Le Guen N, Annesi-Maesano I, et al. (2008) Asthma in France in 2006: Prevalence and symptom control.

2. Adams RJ, Smith BJ, Ruffin RE (2000) Factors associated with hospital admissions and repeat emergency department visits for adults with asthma. Thorax 55: 566-573.

3. Balter M, Ernst P, Watson W, Kim H, Cicutto L, et al. (2008) Asthma worsenings: Approaches to prevention and management from the asthma worsenings working group. Can Respir J 15 Suppl B: 1B-19B.

4. Lahdensuo A (1999) Guided self-management of asthma-how to do it. BMJ 319: $759-760$.

5. Schacher C, Dhein Y, Münks-Lederer C, Vollmer T, Worth H (2006) Evaluation of a structured outpatient education program for adult asthmatics. Dtsch Med Wochenschr 131: 606-610.

6. Beauchesne MF, Levert V, El Tawil M, Labrecque M, Blais L (2006) Action plans in asthma. Can Respir J 13: 306-310.

7. Sarver N, Murphy K (2009) Management of asthma: New approaches to establishing control. J Am Acad Nurse Pract21: 54-65.

8. Tousman S, Zeitz H, Bristol C, Taylor L (2006) A pilot study on a cognitivebehavioral asthma self-management program for adults. Chron Respir Dis 3: 73-82.

9. McDonald VM, Gibson PG (2006) Asthma self-management education. Chron Respir Dis 3: 29-37.

10. Janson SL, McGrath KW, Covington JK, Cheng SC, Boushey HA (2009)
Individualized asthma self-management improves medication adherence and markers of asthma control. J Allergy Clin Immunol 123: 840-846.

11. Coffman JM, Cabana MD, Yelin EH (2009) Do school-based asthma education programs improve self-management and health outcomes? Pediatrics 124: 729-742.

12. Thoonen BP, Jones KP, van Rooij HA, van den Hout AC, Smeele I, et al. (1999) Self-treatment of asthma: Possibilities and perspectives from the practitioner's point of view. Fam Pract 16: 117-222.

13. Backer V, Ulrik CS, Harving $H$, Lange $P$, Søes-Petersen U, et al. (2007) Management of asthma in adults: Do the patients get what they need-and want? Allergy Asthma Proc 28: 375-381.

14. Reddel HK (2007) The benefit of experience: Patient perception of asthma selfmanagement. Prim Care Respir J 16: 68-70

15. Ftohy EM, Abdel-Gawwad ES, Kamal MM, El-Bourgy MD, El-Mallawani H (1999) Cognitive predictors of self-management behavior of asthmatic children and their families in Alexandria. J Egypt Public Health Assoc 74: 439-461.

16. Godard P, Clark TJ, Busse WW, Woolcock AJ, Sterk P, et al. (1998) Clinical assessment of patients. Eur Respir J Suppl 26: 2S-5S.

17. GINA Report, Global Strategy for Asthma Management and Prevention. Global Initiative for Asthma (GINA).

18. Juniper EF, Buist AS, Cox FM, Ferrie PJ, King DR (1999) Validation of a standardized version of the Asthma Quality of Life Questionnaire. Chest 115: 1265-1270.

19. Vollmer WM, Markson LE, O'Connor E, Sanocki LL, Fitterman L, et al. (19990 Association of asthma control with health care utilization and quality of life. Am J Crit Care Med 160: 1647-1652.

20. Blaiss MS (2005) Asthma disease management: A critical analysis. Ann Allergy Asthma Immunol. 95: S10.

21. Lemaigre $V$, Van den Bergh $O$, Van Hasselt $K$, De Peuter S, Victoir A, et al. (2005) Understanding participation in an asthma self-management program. Chest 128: 3133-3139.

22. Creer TL, Caplin DA, Holroyd KA (2005) A self-management program for adult asthma: part IV, Analysis of context and patient behaviors. J Asthma 42: 455-462.

23. Cowie RL, Underwood MF, Sin DD, Sharpe HM, Bell NR, et al. (2006) Calgary COPD and Asthma Program; Alberta Strategy to Help Manage Asthma. Asthma control and management in the community: Indices in 1997 compared with indices in 2002. Can Fam Physician 52: 750-751.

24. Ng TP, Lim TK, Abisheganaden J, Eng P, Sin FL (2006) Factors associated with acute health care use in a national adult asthma management program. Ann Allergy Asthma Immunol 97: 784-793.

25. Partridge MR, van der Molen T, Myrseth SE, Busse WW (2006) Attitudes and actions of asthma patients on regular maintenance therapy: the INSPIRE study. BMC Pulm Med 13: 6-13.

26. Huang TT (2007) Self-care behavior of adult asthma patients. J Asthma 44 613-619.

27. CDC (2003) Asthma self-management education among youths and adultsUnited States, 2003. MMWR Morb Mortal Wkly Rep 56: 912-915.

28. Indinnimeo L, Bonci E, Capra L, La Grutta S, Monaco F, et al. (2009) Clinica effects of a Long-term Educational Program for children with asthma-Aironet. A 1-year randomized controlled trial. Pediatr Allergy Immunol 20: 654-659.

29. Pacheco Y, Zureik M, Dussopt C, Thiriet C (1999) Patient knowledge of asthma: Results of a national survey in pneumology. Rev Pneumol Clin 55: 353-363.

30. Gibson PG, Coughlan J, Wilson AJ, Abramson M, Bauman A, et al. (2000) Selfmanagement education and regular practitioner review for adults with asthma. Cochrane Database Syst Rev 2: CD001117.

31. Foliaki S, Fakakovikaetau T, D'Souza W, Latu S, Tutone V, et al. (2009) Reduction in asthma morbidity following a community-based asthma selfmanagement programme in Tonga. Int J Tuberc Lung Dis 13: 142-147.

32. Huang TT, Li YT, Wang CH (2009) Individualized programme to promote selfcare among older adults with asthma: Randomized controlled trial. J Adv Nurs 65: 348-358.

33. Lavoie KL, Bouchard A, Joseph M, Campbell TS, Favreau H, et al. (2008) Association of asthma self-efficacy to asthma control and quality of life. Ann Behav Med 36: 100-106. 
Citation: Devouassoux G, Freymond N, Laforest L, Vitry T, Cazaux A, et al. (2017) Impact of Long-term Employment of a Self-Management Program in Asthmatics. J Pulm Respir Med 7: 426. doi: 10.4172/2161-105X.1000426

Page 7 of 7

34. Juth V, Smyth JM, Santuzzi AM (2008) How do you feel? Self-esteem predicts affect, stress, social interaction, and symptom severity during daily life in patients with chronic illness. J Health Psychol 13: 884-894.

35. Laforest L, El Hasnaoui A, Pribil C, Ritleng C, Schwalm MS, et al. (2009) Asthma patients' perception of their ability to influence disease control and management. Ann Allergy Asthma Immunol 102: 378-384.

36. Kotses H, Harver A, Humphries CT (2006) Home monitoring in asthma selfmanagement. J Asthma 43: 649-655.

37. Kaya Z, Erkan F, Ozkan M, Ozkan S, Kocaman N, et al. (2009) Selfmanagement plans for asthma control and predictors of patient compliance. $\mathrm{J}$ Asthma 46: 270-275.

38. Côté J, Cartier A, Malo JL, Rouleau M, Boulet LP (1998) Compliance with peak expiratory flow monitoring in home management of asthma. Chest 113: 968-972.

39. Li JT, Sheeler RD, Offord KP, Patel AM, Dupras DM (1999) Consultation for asthma: Results of a generalist survey. Ann Allergy Asthma Immunol 83: 203-206.

40. Wu AW, Young Y, Skinner EA, Diette GB, Huber M, et al. (2001) Quality of care and outcomes of adults with asthma treated by specialists and generalists in managed care. Arch Intern Med 161: 2554-2260.
41. Kanter LJ, Siegel CJ, Snyder CF, Pelletier EM, Buchner DA, et al. (2002) Impact of respiratory symptoms on health-related quality of life and medical resource utilization of patients treated by allergy specialists and primary care providers. Ann Allergy Asthma Immunol 89: 139-147.

42. van der Meer V, van Stel HF, Detmar SB, Otten W, Sterk PJ, et al. (2007) Internet-based self-management offers an opportunity to achieve better asthma control in adolescents. Chest 132: 112-119.

43. George M, Campbell J, Rand C (2009) Self-management of acute asthma among low-income urban adults. J Asthma 46: 618-624.

44. Lougheed MD (2007) Variability in asthma: Symptom perception, care, and outcomes. Can J Physiol Pharmacol 85: 149-154.

45. Rhee H, Belyea MJ, Ciurzynski S, Brasch J (2009) Barriers to asthma selfmanagement in adolescents: Relationships to psychosocial factors. Pediatr Pulmonol 44: 183-1891.

46. Solberg KE (2008) Telemedicine set to grow in India over the next 5 years. Lancet 371: 17-18. 